\section{Filling the information breach}

From Sydney, Peter Pockley looks at Australia's science policy in light of the Science Department's recent Annual Report

SoMEwhat dated and dented by more recent political and bureaucratic changes, the Annual Report of the Australian Department of Science and Consumer Affairs for the year July 1974 to June 1975 has now surfaced. The most visible dent on the Department is the recent removal of consumer affairs from its title and duties.

Nonetheless, this retrospective report is useful, if only for combining in one list the various activities which, under the now deposed Labor administration, had been brought under the one department. It is, however, as informative to note the omissions from this list as the inclusions, for Labor's Department of Science and Consumer Affairs exercised only partial coverage of the national science scene, a situation unchanged under the new regime. By international comparison, Australia spends in the government sector one of the highest proportions of total research funds (of the order of three-quarters). National figures are not yet available for the year in question, but a conservatively generous estimate puts the Department of Science's proportion of this expenditure (that is, funds directly controlled by the Department) at no higher than a quarter, probably less. At least three-quarters of "in-house" government-financed research was done outside the Department's control.

The most obvious organisation standing beyond the influence of the Department is Australia's colossus of research, CSIRO, with expenditure of $\$ 143$ million in 1974-75. In company with the newer and smaller statutory bodies, the Anglo-Australian Telescope and the Australian Institute of Marine Science, CSIRO remained responsible directly to the Minister for Science and Consumer Affairs, and not through his Department. (Again, this arrangement did not change with the change in government in December 1975.)

While a lack of mention of CSIRO in the Department's report is strictly correct in legislative terms (indeed, if the proudly independent CSIRO had been mentioned by the Department from which they keep a cool distance, there could have been a row of epic proportions), it means, unfortunately, that the report cannot be treated by local or international readers as representative of the national science scene.

It should also be added that sub- stantial government-financed research and development efforts are also carried on outside the responsibility of the Science Minister. Notable among these are the Australian Atomic Energy Commission, the Bureau of Mineral Resources, and the Weapons and Aeronautical Research Laboratories, who all report to separate Ministers.

What the Science Department report does show, though, is the dominance within the Department, measured in terms of staff and expenditure, of five operational research and service units, each of which had been long established under other Departments before Labor placed them under the Department of Science from December 1972 onwards.

Out of a total of 3,368 established positions, these operational units had 3,097 and the central office 271 . The Bureau of Meteorology ( $\$ 31.2$ million), the Patent, Trade Marks and Design Office (\$5.7 million), the Antartic Division (\$4.5 million), the Analytical Labortories (\$2.7 million) and the small Ionospheric Prediction Service $(\$ 600,000)$ accounted for $78 \%$ of the Department's overall expenditure of $\$ 57.2$ million. If $\$ 8$ million of payments to university researchers by the Australian Research Grants Committee are included, the proportion of these six activities rises to $92 \%$. Through revenue earned, the Patent office was almost entirely self-supporting, and the Bureau of Meteorology earned over a third of its keep, the total revenue of the Department being $\$ 17.5$ million.

\section{AAT change}

THE 3.9-metre Anglo-Australian Telescope (AAT) on Siding Spring Mountain, New South Wales, is to have a new Director in September. $\mathrm{He}$ is Professor Donald Morton, of Princeton University, and he succeeds Professor E. J. Wampler who left at the end of last month to return to the Lick Observatory in California. Wampler's appointment was for a period of two years ending in October, but by "mutual agreement" he has withdrawn early-mainly because he considered complete his task of seeing the AAT commissioned, but also, it is believed, because he was not completely happy about future prospects for the telescope at a time of economic stringency.

Not that the telescope is lacking funds, according to Professor Vincent Reddish. of the Royal Observatory Edinburgh, who sits on the AAT
The Department also administers civilian space projects conducted through the operations of three tracking stations for the American NASA. Of the 400 employees in this work, only 40 are Australian public servants; the $\$ 11$ million cost in 1974-75 was met by NASA.

The Department can point to an apparently modest sum of $\$ 2.6$ million being spent on general administration. However, the operational units had largely self-contained administrations before their transfer to the Department, and the geographical separation from Canberra of most of them had probably not allowed much in the way of reduced administrative expenses. The Department talks of developing "staff resources without any significant increase in numbers", and of units becoming "more effective as a result of reorganisation". Personalities aside, it is not surprising that friction did develop between the central administration and some of its operational outposts; naturally none of this emerges in the report.

\section{Policy influence}

The constraints on an Australian Department Head in writing a report to his Minister are such that only the blandest information on matters of policy and planning is presented. For instance, Sir Hugh Ennor's report does note the formation of the Interim Australian Science and Technology Council (ASTEC) as "an important, but not exclusive, source of advice to the Government". The report adds that "the Department's work will both supplement and complement ASTEC;

Board. Its present annual budget is about $£ 1$ million, equally financed by the UK and Australia, and, says Reddish, all the indications are that it will continue to be well looked after by the two governments as an important ongoing project.

One of the most interesting aspects of the AAT is the way in which it has been operated hand-in-glove with the UK 48-inch Schmidt Telescope, located a few yards away on the same mountain. The Schmidt is essentially a survey instrument, and on most days AAT astronomers are to be seen in the Schmidt building poring over the most recent plates to find astronomical objects worthy of more detailed examination by the AAT. Much useful work on the spectrometry of faint galaxies, and the dynamics of groups of them, for example, has been done by the AAT in tandem with the Schmidt.

Roger Woodham 